

\title{
色コントラストと可読性に関する実験研究
}

\author{
正会員 舟 川 政 美（日産自動車株式会社）
}

\section{Psychophysical Studies on Legibility and Chromatic Contrast}

Member Masami Funakawa (Nissan Motor Co. Ltd.)

\begin{abstract}
Color differences in the CIE $1976 L^{*} a^{*} b^{*}$ color space were scaled by measuring the critical area of detection with a colored patch on a white background. Several colors were selected to all have the same chromatic contrast with the white background but differ from one another in hue. The legibility of numerals painted with the selected colors were evaluated under Gaussian luminance noises. We found that red and green numerals were more legible than yellow and blue ones, despite the equalized chromatic contrast. The results are explained by differences in spatio-temporal resolution limits, which were estimated from the cut $^{-}$off frequencies of chromatic ${ }^{-}$contrast sensitivity functions measured for different hues.

The following properties of color vision must be kept in mind for coloring a legible display : (1) the low spatio-temporal resolution of chromatic systems compared with that of a luminance system; (2) the decolorization in the peripheral visual field ; (3)the deterioration of color discrimination, caused by aging or several types of color deficiencies ; (4)the wavelengthdependent loss of luminance, caused by aging or several types of color deficiencies ; (5) the lower spatio-temporal resolution for yellow and blue relative to red and green.
\end{abstract}

KEYWORDS : color, chromatic contrast, legibility, visibility

\section{1. 緒言}

情報表示の見やすさ・わかりやすさに対する社会的要請を背景 として, 表示を構成する文字やアイコンのコントラスト, 大きさ, 配置等の最適化が試みられている ${ }^{1) 2}$. 本研究では, 視覚情報の伝 達を媒介している 2 つのントラスト, 即ち, 輝度コントラスト と色コントラストの性質について考察し, 表示デザインの審美性 や快適性に重要な影響を与える色彩について，可読性の観点から 実験的検討を行った。情報を伝えるという実用性を有子る製品に あっても，デザイン優先やファッション性を理由にしばしば使い やすさを犠牲にしたデザインが見受けられるが，高龄者や様々な タイプの視覚障青者等の視覚弱者にとってそのようなデザインは 障害となっている．輝度コントラストと色コントラストに対する 人間の視覚特性を理解し, 两者を適切に使い分けることによって, 多くの改善が得られると思われる。

\section{2. 色コントラストと視認性}

各種表示機器が我々に伝える情報は, 明るさの差異と色の差異 によって表現されている，前者が輝度コントラスト，後者が色コ ントラストである。視覚情報処理過程においても, 両者は心理物 理学的に区别され, 輝度千ャネル, 色チャネルと呼ばれている. 輝度コントラストは, 分光エネルギー分布と比視感度から計算さ れる輝度に基づいて定義され, 明るさの差異を表す尺度として広
く利用されている。しかし，色コントラストを定量的に扱うため の定義や色コントラストを测る共通のものさしはなく, 等色差性 を備えた色度図もない, 従って, 異なる色相の色に対する感度を 比較することも, 輝度コントラストと比較することも, 現時点で はできない. それでも, 錐体反応に基づいた尺度化の試み色や色彩 情報の符号化に関する理論的解析 ${ }^{4}$ などから, 輝度コントラスト に対する感度に較へ，色コントラストに対する感度は，時間的に も空間的にも分解能が低いことが示唆されている。情報の伝達に 拐ける色コントラストの役割を考えると, 可読性の主たる決定因 である時空間分解能が低いことは, 決定的な限界である。高い色 コントラスト感度は, 低時空間周波数領域に限定されており, 輝 度コントラスト感度との機能分化を示唆している。

視野特性や色覚障害や加㱓に伴う視覚機能低下も無視できな い. 色コントラスト感度が中心窩からの離心角に従って低下する ことは，錐体分布，色視野の測定や周辺視野に打ける色の見之を 調べた研究結果5から容易に予測できる．色覚障害の混同色線 ${ }^{6)}$ は, 互いに弁別が難しい色の軌跡を示している. 色覚正常者が谷 易に弁別できる赤と緑や黄と青など反対色の組合せが, 色覚異常 者にとって弁別し難いことを示している，加齢に伴う眼光学系の 光学濃度上昇は, 短波長光に対する感度を選択的に低下させる7 その結果, 高㱓者の低照明下での色弁別特性は, 第 3 色覚異常に 似た様相を示す更。

色覚異常や加㱓は, 輝度の知覚にも影響を与之る。 2 色型第 1 
色覚異常は長波長側， 2 色型第 2 色觉異常は短波長側で視感度が 低下寸るという報告がある ${ }^{97}$. 加齢もまた知波拉側での視感度低 下をもたらすフ。従って，青や赤が暗く見之，邽色によっては，想 定したレベルより殖度コントラストが低下゙する叮能性がある。

情報表示系に扔いて色彩は重要な要素であるが, 色彩を効果的 に利用するには，輝度コントラストと色コントラストに対寸る視 觉特性の違いを旮分に理解しておく必要がある。表示系デザイン のために考慮すべき色覚特性は，(1)色觉の低時空間分解能，(2)周 辺視野における色覚機能の低下，(3)色営其常や加齿に臣因子る色

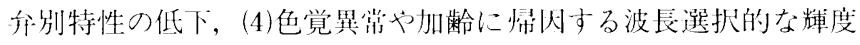
知覚の低下，である。

\section{3. 実験 1 ：色弁別における臨界面積の測定実験}

\section{1 目的}

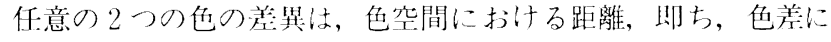
よって表される。本笑験の目的は，色桼を何らかの基準でもって 尺度化することである。本研究では，全ての刺激が CIE $1976 L^{*}$ $a^{*} b^{*}$ 色望間で記述された， $L^{*} a^{*} b^{*}$ 他空間には，2つの色光 $\mathrm{A}, \mathrm{B}$ を加法混色して得られる色光 $\mathrm{C}$ の色度点が, 色光 $\mathrm{A}, \mathrm{B}$ の色度点老 結んだ直線上にないという問題も女るが，応用場面で広く利用さ れており，また，明度・彩度・色相という色の3 属性と色無間軸 との対忍が考えや导いという利苫がある。

空間周波数の関数としての色コントラス卜感度がロ一パス型で

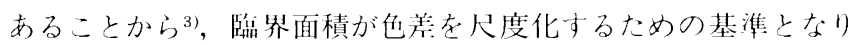
得る。任意の 2 色をそれぞれ背景と視標の出とし，２色の色弁別 が叮能な視標の最小面䅵, 即ち, 臨界面积を測定できる。他差に

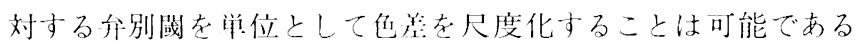
が，分別閾と比較して色差が大きくなるはどその信頼性は低下寸 ると考之られる。また，無彩色背景上のマンセル色典に関して視 恋距離を測定した研究は, 背景との明度差の効果を1とした時, 彩度差が 0.125 , 色相差 10 度が0.0226 と報告している ${ }^{10}$ 。即ち, 視 認距離の大半を決好ているのは輝度コントラス卜である。この報 告は，色彩に上る視認性の差を調べるには，輝度悄報を排除すべ きであることを教えている，多くの研究で，任意の 2 色に関し：

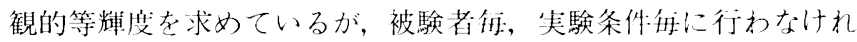
ばならない，本実験では，がウシアン輝度ノイズを付加すること によって，輝度コントラストが視標の検出に与える効果を排除し た。輝度ノイズの付加によって，殖度コントラストに基づいて背 景と視槽老区別することはできなくなり，色コントラストによっ てのみ北景と視標とが区別されると仮定できる.

本奏騃で色分別に扮ける臨界面皘を測定した 2 色の一方は，常 に無彩色であった。また，色差のう向は，白色点を中心とする 8 方位であり，色差は彩度（クロマ）の差であった。

\section{2 方法}

\section{被験者}

正常色覚を有する 2 名（MF：男性39才, MT：女性29才） 装犆

装置は，フレーム・バッファ (DIGITAL ARTS HyperFrame3) を介しコンピュー夕（NEC PC9801）により生成・制御され，9” カラーCRT（Victor CM-9G72）上に呈示された。観祭者の反応 は，I/Oモジュールを介して反応キー一から上記コンピュータへ入 力された。

刺激

背景及び色視標の色度は, 全て $L^{*} a^{*} b^{*}$ 色空間で記述した. 事前
にディスプレイを测色し，ディジタル画像の RGB 值とディスプ レイ表示の色度との対応付けを行った。画面の平均輝度は，14.5 $\mathrm{cd} / \mathrm{m}^{2}\left(L^{*}=45\right)$ であった。 背景の色座標 $\left(a^{*}, b^{*}\right)$ は $(0,0)$ で あった，背景の座標点を中心に 8 方位に色差 $2 ， 4 ， 8 ， 16,32$ の計40色の色視標（円形）について, 臨界面積 $A_{\mathrm{c}}$ を測定した（色 視標の色度がディスプレイの色域を超える場合, 表示可能で最も 近い值を用いた)。刺激丒面全体には, 輝度コントラストが検出の 手がかりをケえるのを避けるため，がウシアン輝度ノイズ (平均 $\left.L^{*}=45, \sigma=2, \quad 11.3 \sim 18.4 \mathrm{~cd} / \mathrm{m}^{2}\right)$ 考付加した. 色視標の呈示位 置は,ディスプレイ中块から左右に 1 度の位置を中心に周囲 $0.5 \times$ 0.5 度の範用でランダムに選択され, 呈示時間は $500 \mathrm{~ms}$ であった。 手続

被験者は, 暗室内で観察距離 $114 \mathrm{~cm}$ からディスプレイ中央を観察 した。被験者の眼は, 顎台により固定され, 岘眼視, 自然瞳孔で 観察した.セッションの最初に検出すべき色視標が秒間呈示され た。試行は，ビープ音により始まり，被験者は，色視槽が画面の 右側に呈示されたか左側に圼示されたかを判断した（強制選択）. 反忍には, 正䛊のフィードバックが与えられた. 正成応が 2 度連 続した場合, 次試行で呈示される色視標の大きさは縮小し, 䛊反 応の場合, 逆に拡大した。この手続きを繰り返し(上下法), 正䛊 の反応の変換点における複数のデー夕の幾何平均から, 正答率約 $70 \%$ に相当与る閾值（臨界面積）が決定された。

\section{3 結果}

図 1 に，背景の色度を中心に 8 方位の色相毎に，色差（彩度あ るいはクロマの差）の関数として臨界面積の測定結果を示寸。ま た, 図 1 の中央に臨界面積を基準に被験者毎に求めた等感度曲線 を示す.

色視標と背景との色差が小さいほど，臨界面積は大きくなり， その関係は, 心゙き関数で記述できた。べき関数の各係数は, 被験 者及び背景色からの色差の方位（色相角）によって異なっている. 等感度曲線は， $b^{*}$ 軸から反時計回りの方向に約45度傾けた軸を長 軸とする楕円形をしており, MacAdamの色弁別楕円と同様の形 状と傾きである ${ }^{11)}$ 。また，総じて，第 2 象限 (Munsell hue $Y-G$ ) と第 4 象限 (RP-PB) で感度が低く, 第 2 象限が最も感度が低い. 結果は, $L^{*} a^{*} b^{*}$ 色空間の等色差性の不完全さを反映している. ま た，色視標を拡大することは，低空間周波数帯域におけるパワー を增加させることであるから，本結果は，各色相における低空間 周波数帯域に拀ける感度と相関していると考之られる。

\section{4. 実験 2：色文字の可読性評価実験}

\section{1 目的}

春験 1 の絬果に基づいて, 臨界面積をものさしとして, 背景と の色コントラストが等しく, 色相が巽なる複数の色を設定するこ とができる。これらの色を使って，色相による可読性の差異を測 定するのが，本実験の月的である．視認性における色彩の効果に 関して，多くのデザイ十を悩ませている問題は，色相によって視 認性に違いがあるか，という問題である。色コントラス卜感度は, 空間分解能が低く, 色コントラストのみによって定義された文字 の可読性は低いことが予想されるが, 色相によって差異があるか 否かは不明である。

\section{2 方法}

被騃者

正常色覚を有古る2名（MF：男性39才, MT：女性29才) 装置 

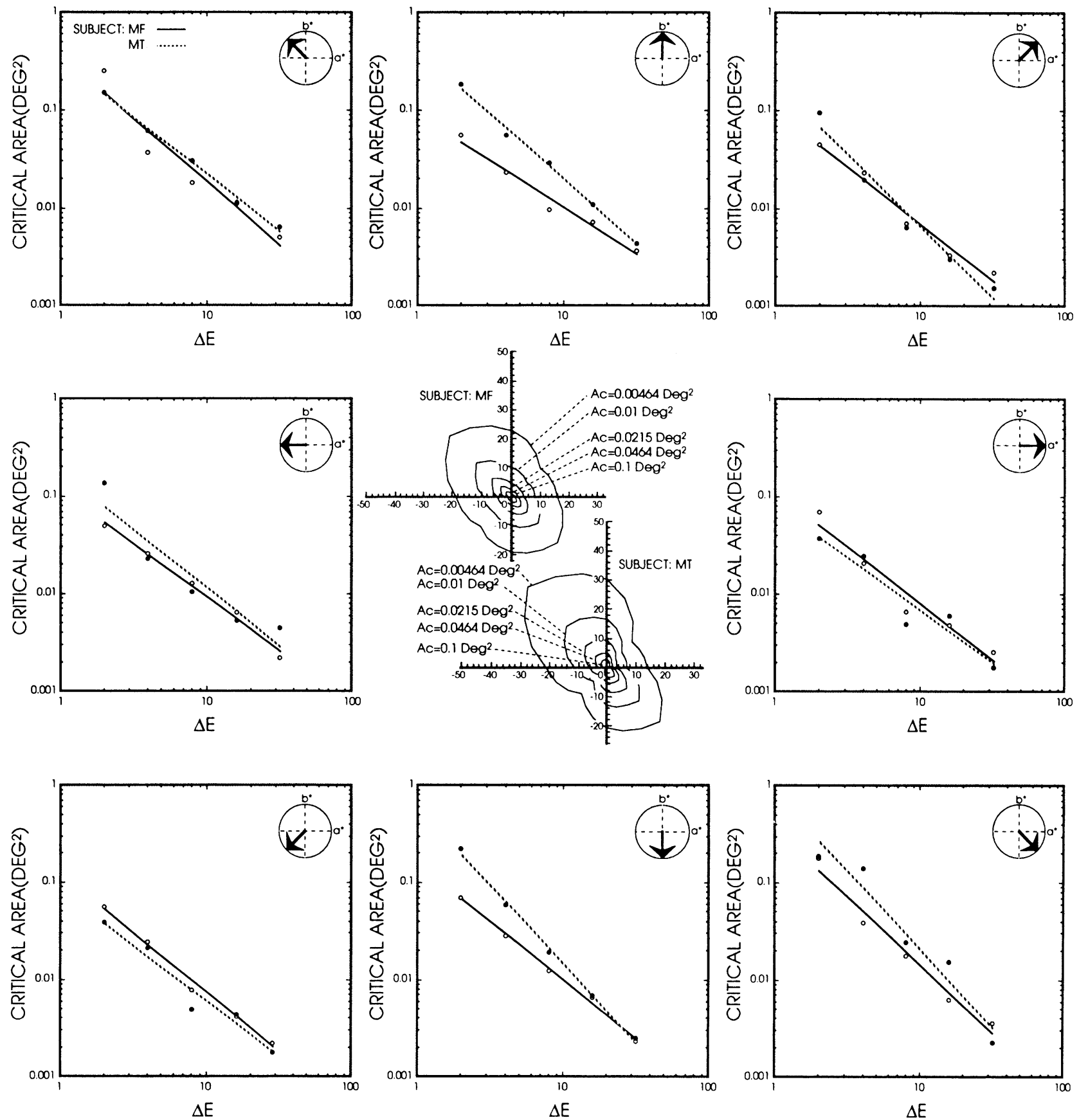

図 1 実験 1 の結果. 色相毎の臨海面積と等感度線

Fig. 1 The critical areas measured by different hues and the equi-sensitive contours.

実験 1 と同一の装置を使用した。

刺激

刺激としてセグメント型の数字書体 $(0$ ～8 ) を使用した（図 2 参照)。文字サイズは，視角 $0.35(W) \times 0.66(H)$ 度であった。 被験者每に, 無彩色 $\left(a^{*}, b^{*}\right)=(0,0)$ を中心に色環を成す 8 種の色相について, 臨界面積を基準に等色コントラスト (等彩度) の色を計算した。背景との色コントラストは，3段階（低・中 · 高, それぞれ臨界面積 $A_{\mathrm{c}}=0.01,0.00563,0.00316 \mathrm{DEG}^{2}$ に対応） とした (四 2 参照)。被験者毎に選択された色座標を図 3 に示す。 可読性測定は，(1)無彩色背景上の有彩色文字，(2)有彩色背景上の 無彩色文字，(3)有彩色背景上の有彩色文字（彩度高の条件のみ）
の 3 条件で行った。条件(1), (2)の無彩色は, 実験 1 の背景色 $\left(a^{*}\right.$, $\left.b^{*}\right)=(0,0)$ と同じであった。条件(3)の文字色は, 高彩度条件の $a^{*}, b^{*}$ 軸上にある 4 色, 背景色は, 色座標上で文字色の反対側に 位置する 5 色とし, 合計 20 通りの組合せについて可読性測定を行 った. 条件(3)の有彩色の各色対は, 相互にその色コントラストを 比較することはできない。ここでは，探索実験の意味合いでこの 条件を設定した. 実験 1 同様, 画面の平均輝度は $14.5 \mathrm{~cd} / \mathrm{m}^{2}\left(L^{*}=\right.$ 45）とし, 輝度コントラストが数字の読み取りの手がかりを与之 ないよう, 刺激画面全体にガウシアン輝度) イズ (平均 $L^{*}=45$, $\left.\sigma=2,11.3 \sim 18.4 \mathrm{~cd} / \mathrm{m}^{2}\right)$ を付加した.

手続き 
$A_{C}=0.01 D E G^{2}$
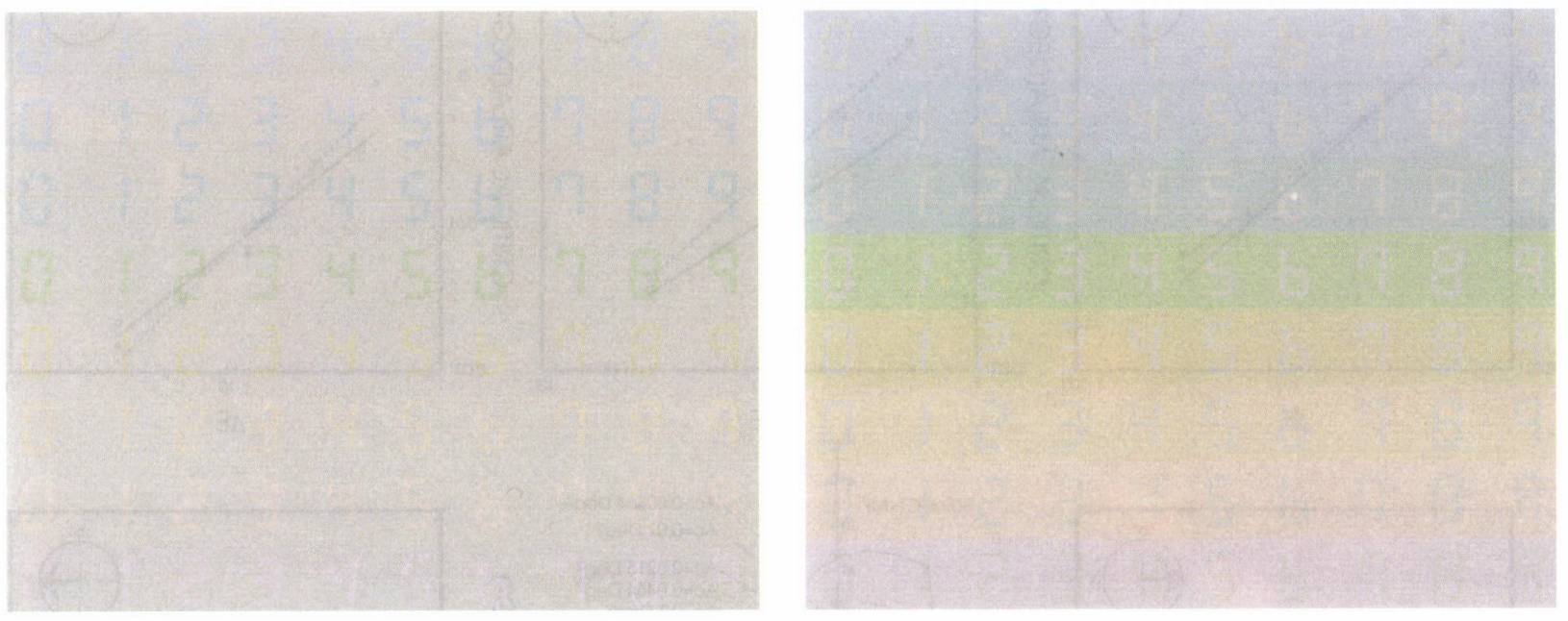

$A_{C}=0.00563 D E G^{2}$
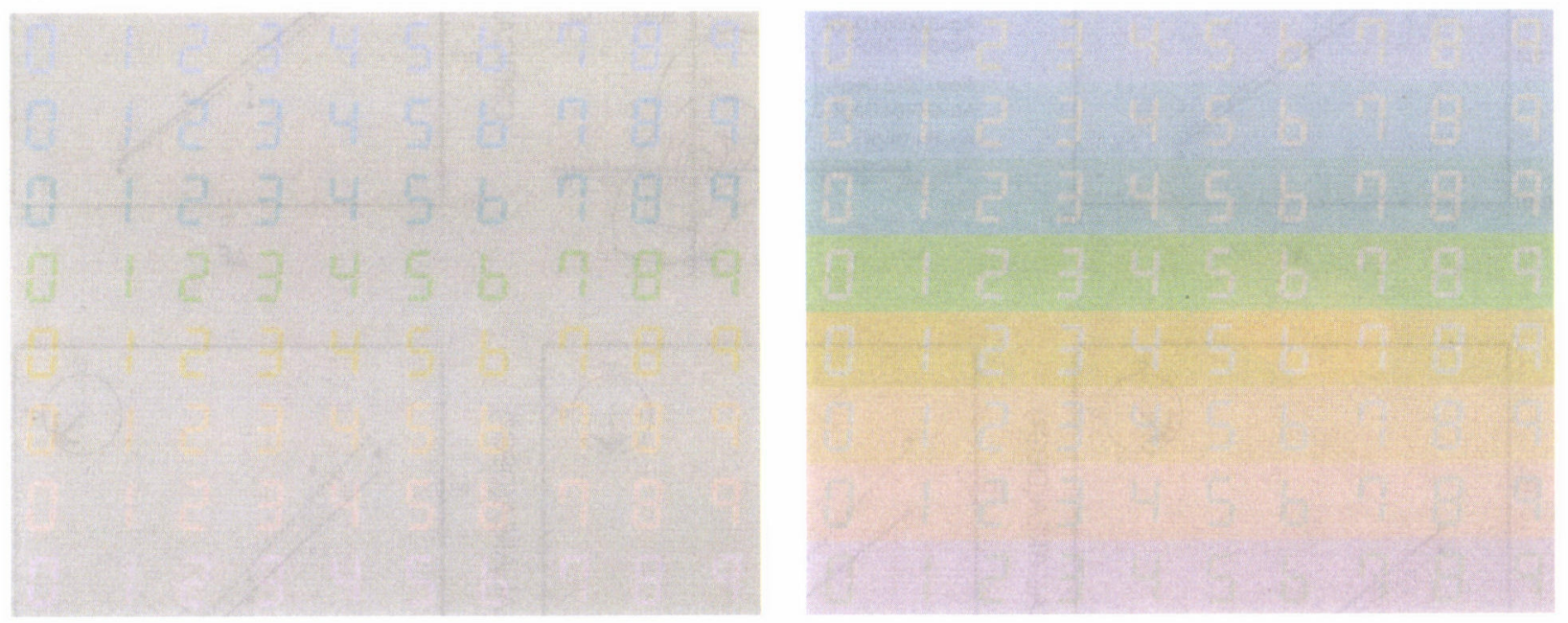

$A_{C}=0.00316 D E G^{2}$
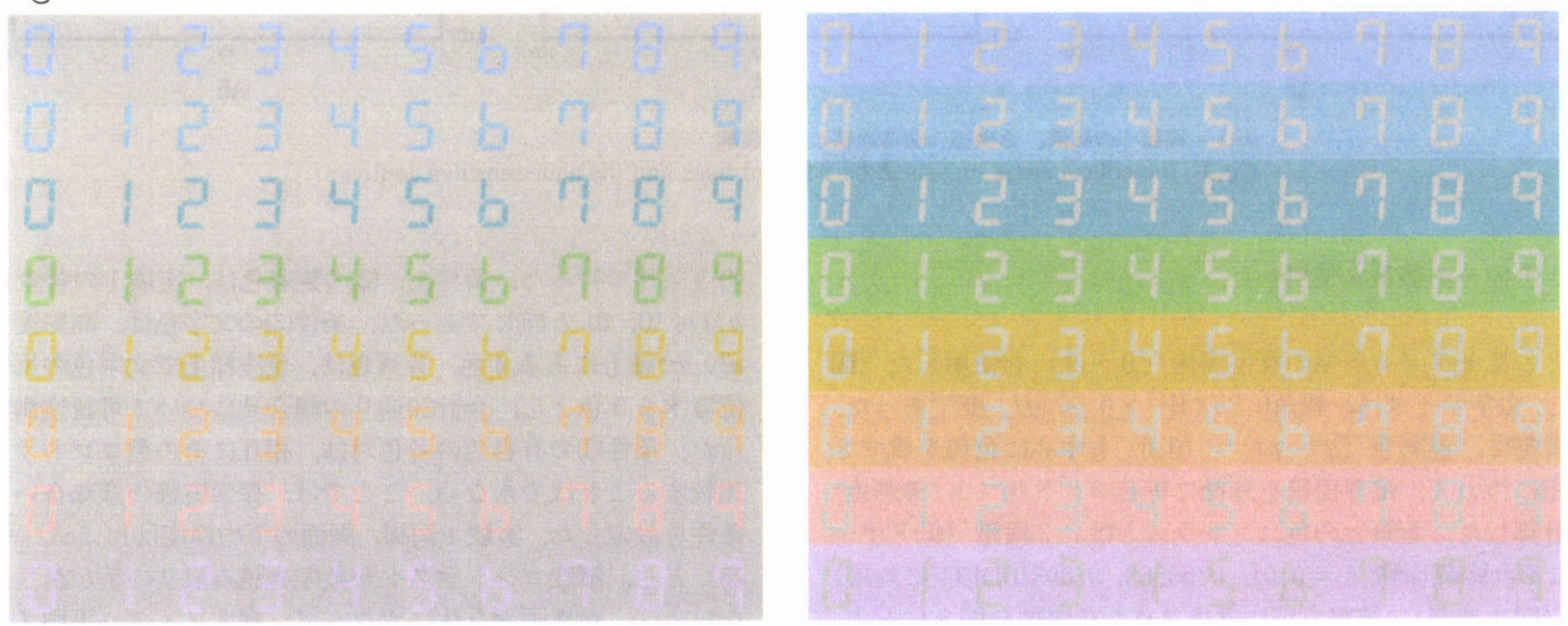

図 2 可読性評価用の刺激文字

Fig. 2 The colored numerals with luminance noises. 


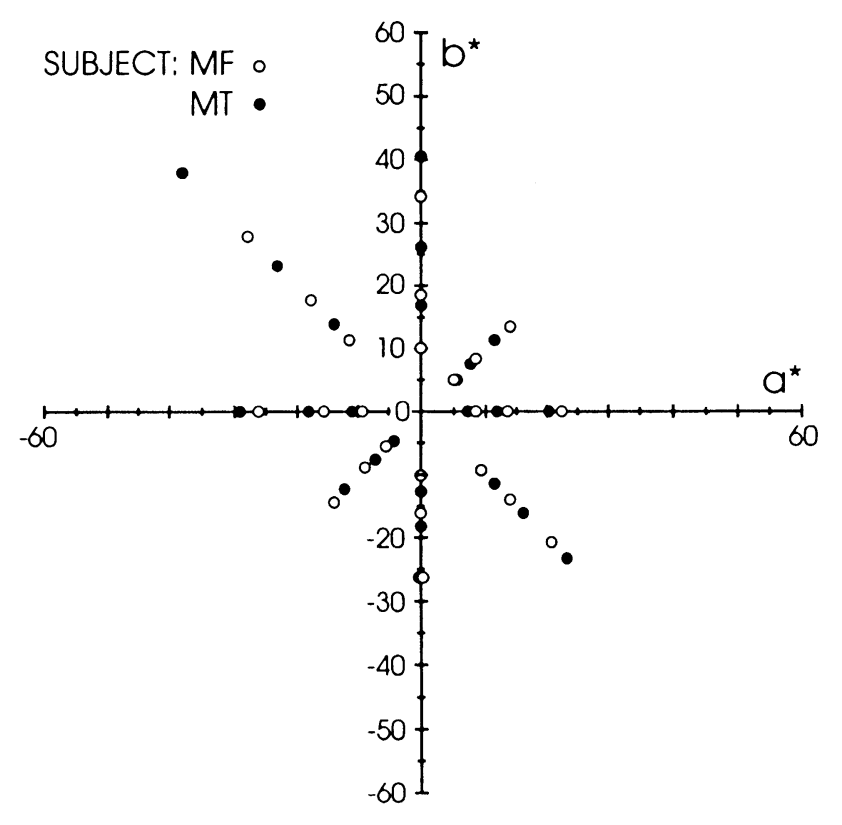

図 3 可読性評価に用いた色の色度

Fig. 3 Chromaticities of the stimulus colors.

被験者は，暗室内で，観察距離 $114 \mathrm{~cm}$ から，ディスプレイ中央の 凝視点を観察した。被験者の眼は, 顎台により固定され，再眼視， 自然瞳孔で観察した。

刺激条件(1)，(2)，(3)，及び 3 種の色コントラスト条件每に可読 性評価実験を行い，各実験では背景色と文字色の組合せ毎の可読 性を測定した，各試行では，検出すべきターゲット文字が最初に 呈示され，ビープ音の後，ランダムに選択された 8 個の文字がデ イスプレイに継時的に，呈示された（Inter-stimulus interval= 0 )。試行毎にターゲット文字がランダムに選択・呈示され, 従っ て，得られた可読性測定值は，0８の数字セットに対する評価 值となる，数字の向きは，常に正立で，位置は，凝視点を中心に $1.65(W) \times 1.93(H)$ 度の矩形領域内でランダムに変化した。被 験者は，呈示された文字系列の中にターゲットがあったか否かを 判断し (強制選択), 手元の 2 つの反忘キーのどちらかを押した. 反応には，正誤のフィードバックが与えられた。ターゲット文字

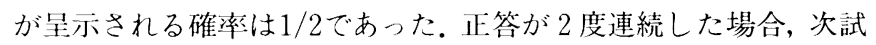
行におけるフレーム呈示時間（一文字当たりの呈示時間）が短く なり，誤答の場合は，逆に，長くなった。この手続きを繰り返し

(上下法), 正誤の反応の変換点に扔ける複数のデータの幾何平均 から，正答率約 $70 \%$ に相当する閾値（フレーム呈示時間）が決定 された。

\section{3 結果}

可読性は，フレーム呈示時間として測定された。結果は，図 4， 図 5 にフレーム周波数（フレーム呈示時間の逆数）に換算してプ ロットした.視覚系において空間分解能と時間分解能は trade off の関係にあるから，フレーム周波数が高いほど（即ち, 時間周波 数带域が高いほど), 低空間周波数带域を使った読み取りが行われ たことを意味し, 即ち, 可読性が高いと考えられる。結果は, 以 下の様にまとめることができる.

（1）無彩色背景上の有彩色文字でも, 有彩色背景上の無彩色文字 でも，有彩色の色相に関わらず，背景と文字との色コントラス ト (彩度方向の差) が大きいほど，可読性は高い。

（2）無彩色背景上の有彩色文字でも, 有彩色背景上の無彩色文字
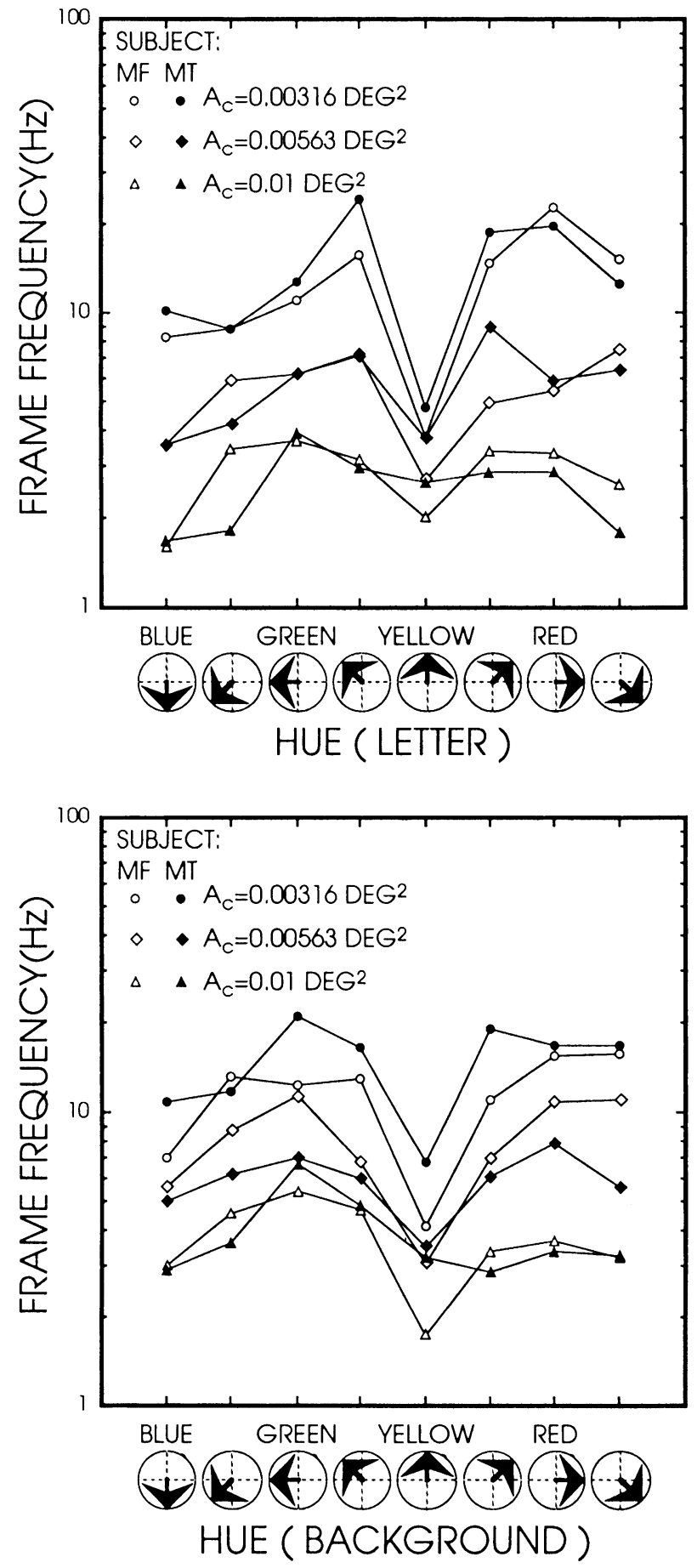

図 4 実験 2 の結果. 色文字の可読性

Fig. 4 The results of legibility evaluation of the colored numerals.

でも，赤・緑に較べ，黄・青の可読性は低い.

（3）有彩色背景上の有彩色文字の場合，赤・緑文字では，文字と 背景間に予想される色差が大きいほど可読性が高い（逆U 字 型）が, 黄文字では赤や青より緑背景, 青文字では緑や黄より 赤背景の方が可読性が高い ( $\mathrm{S}$ 字型).

臨界面積に基づいて，色コントラストを尺度化したにもかかわ らず，色相間で可読性の差異が見出された。時間周波数（フレー ム周波数）によって可読性を評価したためとすれば，時間周波数 によって色差の効果が変動することを示唆している．有彩色背景 

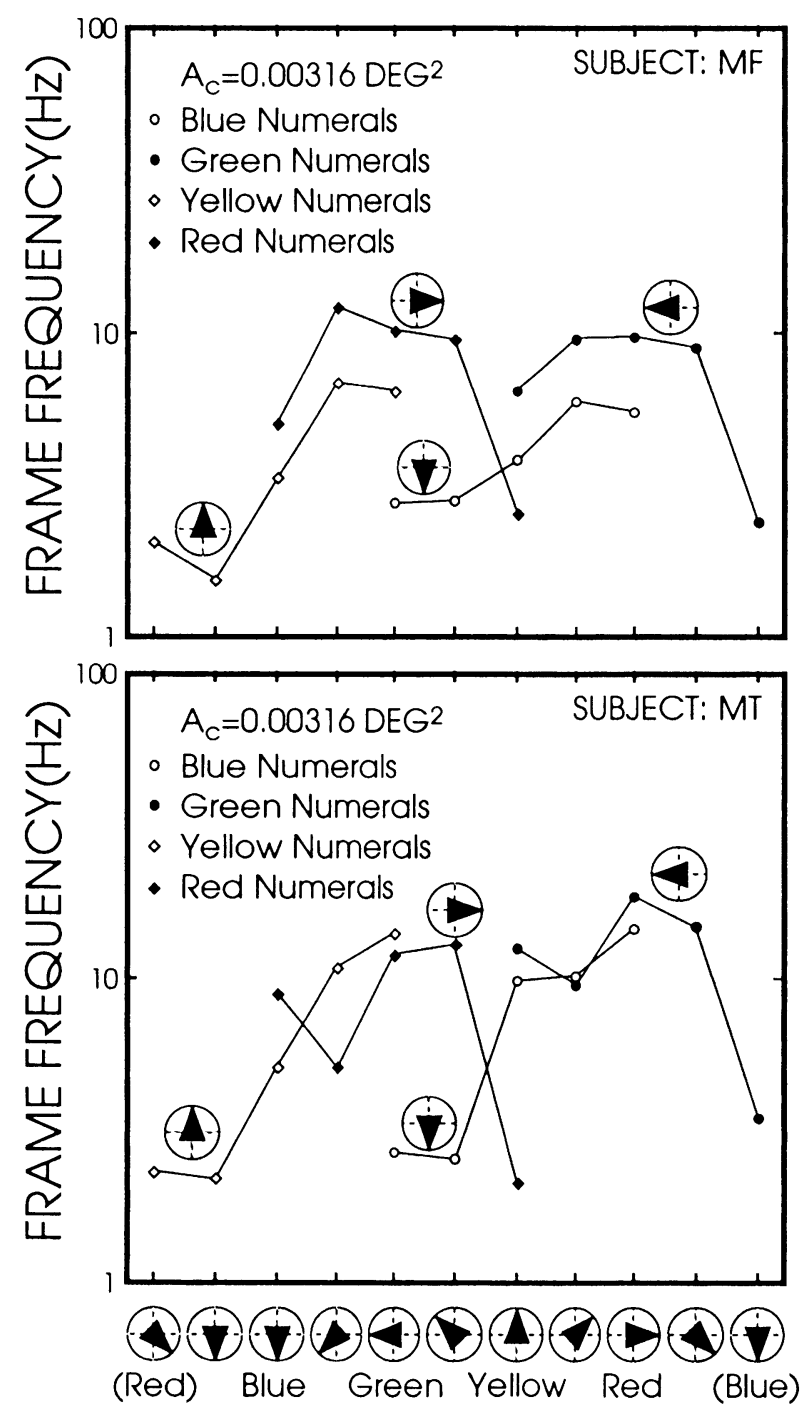

BACKGROUND

\section{図 5 実験 2 の結果. 配色の効果}

Fig. 5 The results of legibility evaluation of the colored numerals.

上の有彩色文字の場合，色差の尺度化は行われていないが，他の 条件同様，その結果を色差で説明することは難しい.

\section{5. 実験 3：色コントラスト感度の測定実験}

\section{1 目的}

実験 2 において見出された色相による可読性の差異は，如何に 説明されるのか，実験 1 に扔いて，色視標を拡大寸ることは，低 空間周波数帯域におけるパワーを増加させることであった。臨界 面積で色コントラストを尺度化することは，各色相に対する色コ ントラスト感度のピーク值, 即ち, 低空間周波数に対する感度を 基準とすることに等しいと推論できる，従って，本実験では，色 コントラスト感度を様々な時空間周波数で測定した。実験 2 にお いて見出された赤や緑に較べ黄と青の色相で可読性が低いこと は, 後者の時空間分解能が低いことを示唆しているからである.

\section{2 方法}

被験者

正常色覚を有する 2 名（MF：男性40才，MT：女性30才） 装置
装置は, フレーム・バッファ(DIGITAL ARTS HyperFrame3) を介しコンピュー夕（NEC PC9821）により生成・制御され，15” カラー- CRT (NEC PC-KD881) 上に呈示された。観察者の反応

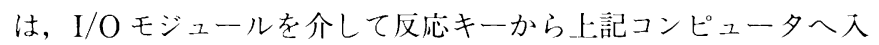
力された。

刺激

刺激は，水平方向に彩度変調する正弦格子にガウス関数を乗じ て作られる Gabor bar であった。色度変調は全て CIE $1976 L^{*} a^{*}$ $b^{*}$ 色空間で行った。平均色度は, $a^{*}, b^{*}$ 軸上にある白, 赤, 緑, 黄，青の 5 色相に近いものとして，また，有彩色の場合ディスプ レイの色域内でできるだけ彩度の高いものとして，それぞれ色座 標 $\left(L^{*}, a^{*}, b^{*}\right)=(50,0,0),(50,40,0),(50,-18,0),(50$, $0,38),(50,0,-30)$ を選んだ。変調軸は，色座標（50, 0,0$)$ の場合のみ $a^{*}$ 軸と $b^{*}$ 軸の 2 通り，その他は彩度方向 $\left(a^{*}\right.$ 軸か $b^{*}$ 軸方向）とした。時間周波数は，0.58，1.15，2.31，4.62Hzの 4 条件, 空間周波数は, $0.13 \sim 12.7 \mathrm{CPD}$ の範囲で14種であった。画 面の大きさは, 観察距離 $114 \mathrm{~cm}$ の時, 視角 $12.6 \times 8.4$ 度であった. 観察距離は, 高空間周波数 $(8.5,12.7 \mathrm{CPD})$ の測定の場合 $228 \mathrm{~cm}$, 低空間周波数 $(0.2,0.13 \mathrm{CPD})$ の測定の場合 $57 \mathrm{~cm}$ と変化した. 正 弦格子の大きさは 3 サイクルで，1 サイクル分左右に移動する間 だけ呈示され，この間，刺激パタン全体が時間的にガウス関数に 従って変調した。刺激呈示開始時における位相は, 試䘕毎にラン ダムであった。平均輝度は, $18.4 \mathrm{~cd} / \mathrm{m}^{2}\left(L^{*}=50\right)$ で, 輝度コント ラストが格子の運動検出の手がかりになるのを避けるため, 刺激 画面全体に $L^{*}$ 值士 5 の範囲のガウシアン輝度)イズ (平均 $L^{*}=$ $\left.50, \sigma=2,14.5 \sim 22.9 \mathrm{~cd} / \mathrm{m}^{2}\right)$ が付加された.

手続き

被験者は, 暗室において, 所定の観察距離から両眼・自然曈孔 で画面中央の凝視点を観察した。被験者の眼は，顎台により固定 された。凝視点が消え, 正弦格子が呈示された。被験者は, 格子 の運動方向 (左右) を判断し, 反応キ一を押した（強制選択）．反 応には, 正誤のフィードバックが与えられた。正答が 2 度連続し た場合, 次試行における彩度変調の振幅は小さくなり, 䛊答の場 合は，逆に，大きくなった。この手続きを繰り返し(上下法), 正 誤の反忘の変換点における複数のデー夕の幾何平均から, 正答率 約70\%に相当する色コントラスト閾が決定された。

\section{3 結果}

色度変調の振幅を色差で表したものを色コントラスト間とし， その逆数を色コントラスト感度とした。 さらに, 最も低い時間周 波数条件で測定した色コントラスト感度の最大值を 1 として, 各 色相毎に標準化した。この操作は, 実験 1 において臨界面積をも のさしに，色コントラストを尺度化したことに対志する。また， 色コントラスト感度測定では, 色収差と回析によって, 想定外の 輝度変調が生じるという問題がある。この効果は, 本刺激画面に は, 色収差や回析によって生じる輝度変調より大きな振幅の輝度 ノイズが付加されていること, 相対的に低い空間周波数を使って いることによって，最小化されていると考之られる. 結果を図6， 図 7 に被験者每, 色相毎に示す。時間周波数条件毎に Gumbel 関 数をフィッティングした. 結果は, 以下のようにまとめることが できる。

（1）どの色相においても, 色コントラスト関数は, 空間周波数に 対しローパス型となった。

（2）どの色相においても，時間周波数上昇によって色コントラス 卜感度は低下した。 
(a)

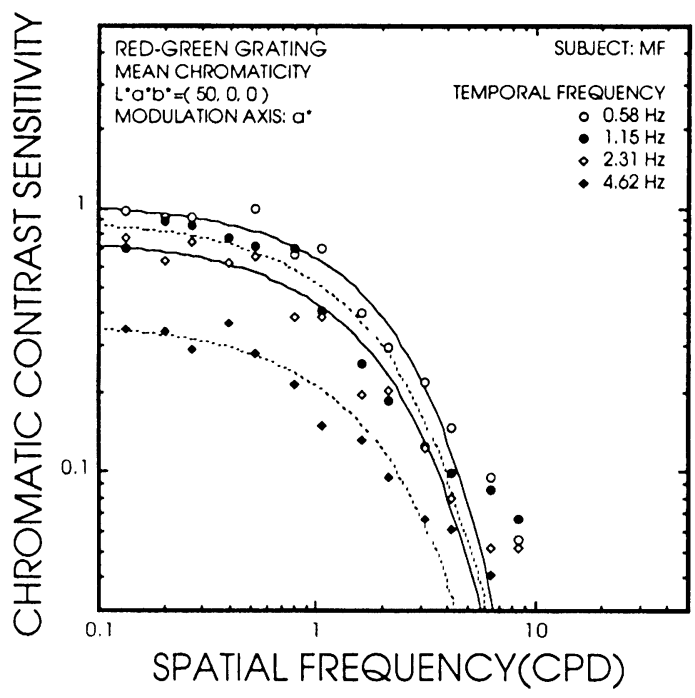

(c)



(e)

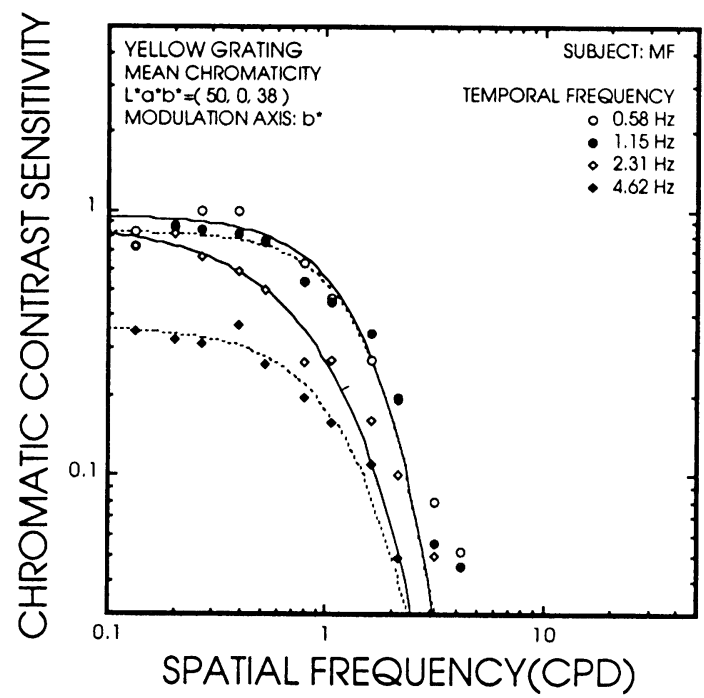

(b)

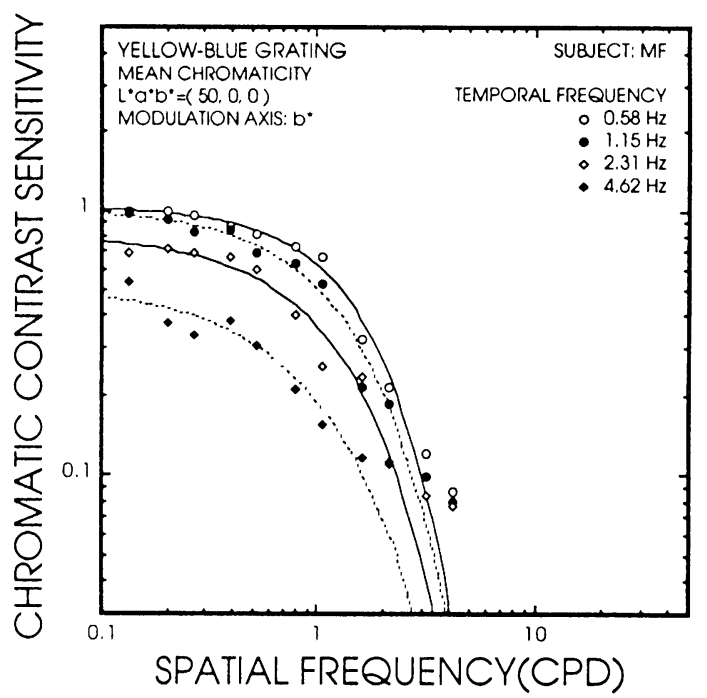

(d)

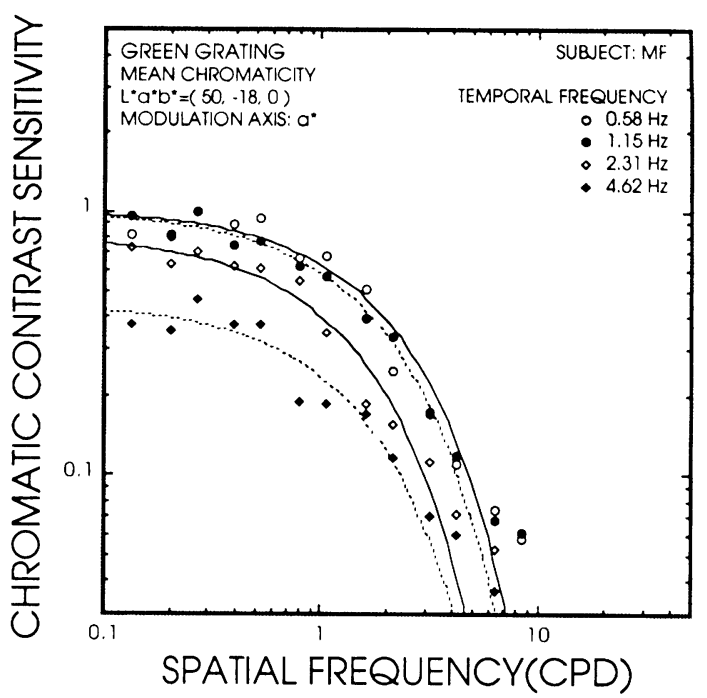

(f)



図 6 実験 3 の結果. 色コントラスト感度（被験者 MF）

Fig. 6 Chromatic contrast sensitivity functions (sub. MF). 

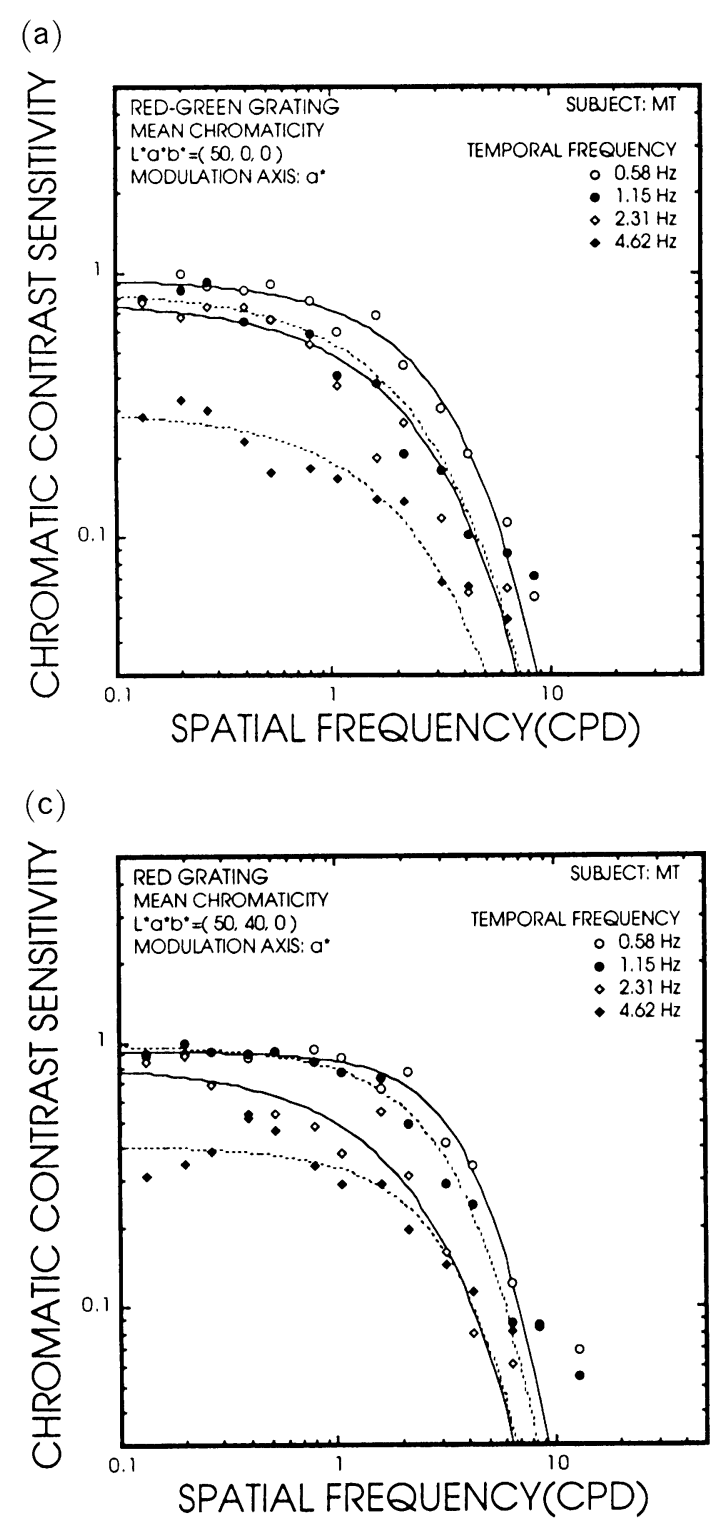

(e)

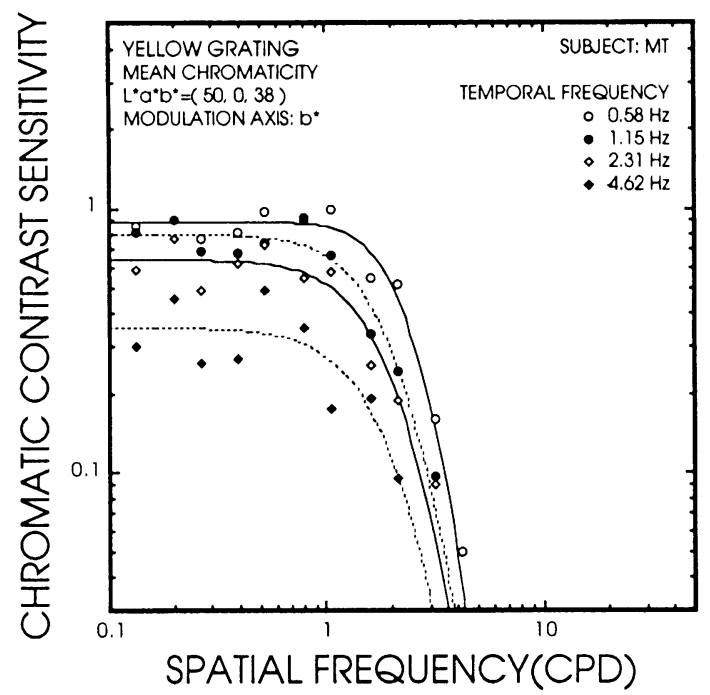

(b)

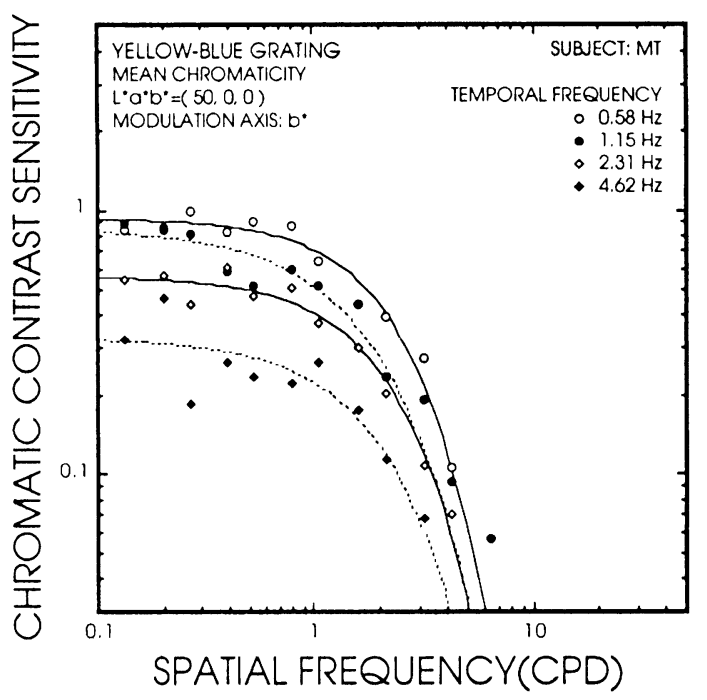

(d)

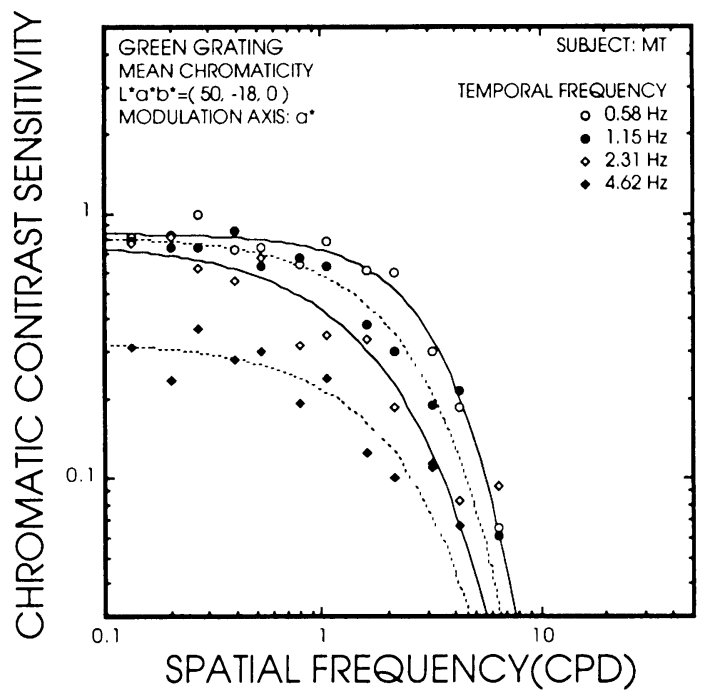

(f)

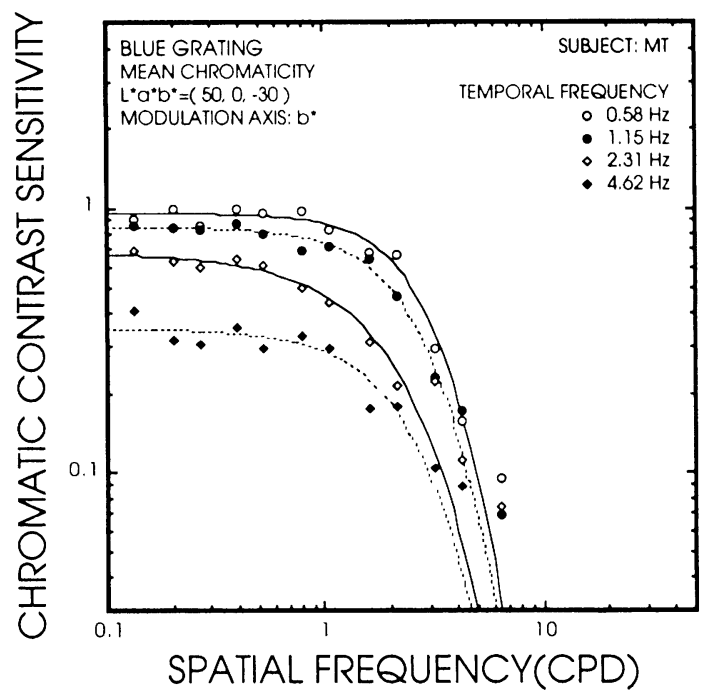

図 7 実験 3 の結果. 色コントラスト感度（被験者 MT）

Fig. 7 Chromatic contrast sensitivity functions (sub. MT). 
（3）平均色度が等しい赤緑格子と黄青格子に対する色コントラス 卜感度関数を比較すると, 後者の方が高周波側のカットオフ周 波数が低くなった。

（4）赤・緑・黄・青の彩度変調格子に対する色コントラスト感度 関数を比較すると, 赤・緑・青・黄の順序でカットオフ周波数 は低くなった。

輝度変調する正弦格子を用いたコントラスト感度測定実験の結 果 ${ }^{12)}$ と本実験結果を比較すると, 測定条件が異なることを考虑に 入れても, コントラスト感度関数の高周波側のカットオフ周波数, 即ち, 空間解像度はかなり低い。輝度チャ不儿に対し, 色チャネ ルの時空間分解能が低いことが示された。

\section{6. 考察}

視覚の時空間分解能に基礎を置く可読性に関して, 色相間で差 異が認められた。本研究において, 色は全て CIE $1976 L^{*} a^{*} b^{*}$ 色 空間において扱われたため，色覚のメカニズムに関して言及寸る には限界がある。本研究で用いた刺激は，色覚機構を構成する 3 種の錐体機構や 2 つの反対色千ャネルの反応を分離するものでは ない.しかし, 本研究結果の基礎には2つの反対色チャ不ル間の 時空間分解能における差異があると，推測できる。

色コントラスト感度関数の高周波側のカットオフ周波数は, 空 間分解能の上限を規定している．実験 3 で見出されたこのカット オフ周波数における色相による差異は, 実験 2 の無彩色背景上の 有彩色文字や有彩色背景上の無彩色文字の条件で見出された色相 による可読性の相違と，ほぼ一致している，実験 2 の有彩色背景 上の有彩色文字の場合, 有彩色同十の色差が尺度化されていない が，様々な配色間に見出された可読性の差異は，色差からは説明 し難い.しかし, 背景か文字のどちらか一方でも, 黄か青だと可 読性が低下寸ることから, 黄青の時空間分解能が相対的に低いこ とを仮定すれば，説明可能であろう。低空間周波数帯域における 感度（即ち，感度の最大值）に基づいて色コントラストの尺度化 を行うと，色相によって時空間分解能に差が生じることは，色覚 を構成する下位モジュール間に時空間分解能の差異があることを 示唆している.

2 つの反対色機構である赤緑千ャネルと黄青チャネルにおい て, 黄青チャネルの時空間分解能が低いことは, $\mathrm{S}$ 錐体が $\mathrm{L} \cdot \mathrm{M}$ 錐 体に較べ密度が極端に低いこと, 黄を符号化するには $\mathrm{L} ・ \mathrm{M}$ 両錐 体の出力が必要なことなどから, 定性的に予想できる. 即ち, 色 変調の符号化のための網膜上のサンプリング周波数は, 赤・緑に 較べ黄・青の方が低い。 また, 操作的に両チャネルの不応を分離 し測定した色コントラスト感度関数 ${ }^{3 / 4}$ から見ても, 妥当な推論で あると考之られる。両千ャネル間の時空閒分解能の差異がこれま であまり重要視されてこなかったのは，色コントラスト感度測定 の方法論的困難さに帰因するデー夕の少なさや，色相による可読 性の差異といった視点を欠いていたことなどのためであろう.

最後に，8種の色相を使った本実験結果，及び，色覚異常者に とって反対色の弁別が困難であること考慮して, 可読性の観点 から配色について有効な指摘ができる. 即ち, 赤青緑黄の順に並 んだ色環において, 約225度の角度をなす2色の配色が可読性の点 から優れているということである。

\section{7. 結語}

CIE $1976 L^{*} a^{*} b^{*}$ 色空間において, 臨界面積を基準に色コント ラストの尺度化を行い, 無彩色との色コントラストが等しい色を
8 種の色相毎に求めた。それらの色を使った数字文字の可読性を 時間周波数を尺度に測定した。その結果，赤・緑に較へ，黄・青 の可読性が低いことが見出された。 CIE $1976 L^{*} a^{*} b^{*}$ 色空間で色 度変調する正弦格子を刺激とし, 様々な時空間周波数で色コント ラスト感度を測定した結果，色コントラスト感度関数の高周波側 のカットオフ周波数が, 赤・緑・青・黄の順で低いことが見出さ れた．文字の可読性の低下と色コントラスト感度関数のカットオ フ周波数の低下には，高い相関があった。

表示系のデザイン要素として色彩を考える際，(1)色覚の低時空 間分解能，(2)周辺視野における色覚機能の低下，(3)色覚異常や加 齢に帰因与る色弁別特性の低下，(4)色覚異常や加齢に帰因する波 長選択的な輝度知覚の低下,の 4 点に配慮与べきであると述べた。 本研究結果から,(5)時空間分解能は赤緑に較べ黄青に対して低い, を付け加えることができる。

本研究の主題である可読性について云えば，色コントラストの 役割は限定されており，可読性は，より時空間分解能が高い輝度 コントラストによって達成されるべきである。輝度コントラスト と色コントラストの機能は，区別しなければならない，視環境を 照らす光が太陽光のような広带域の光である限り，その強度変化 に対し，輝度は大きく变動するが，色の変動幅は小さい，様々な 要因によって輝度ノイズが生じても, 本実験場面の様に, 色コン トラストは知覚される。色彩は，誘目性や快適性とも関連が哚 く ${ }^{13)}$ ，注意や情緒的な反応を促したり，危険・安全・注意・正常・ 異常といった暧昧だが直感的，情緒的な意味を伝えることができ る、視野の分節化や閁地の分化に果た寸役割も大きい，視覚特性 を考虑した見やすい表示系を実現するには，このような色コント ラストの利点を活かし，前述した注意点に配慮しながら，輝度コ ントラストと色コントラストを適切に使い分ける必要がある。

\section{参 考 文 献}

（1）舟川政美，小田浩一：ローパス・フィルタリング法による 形状の視認性評価, 照学誌, 81, pp.438-445 (1997).

(2) 舟川政美：文字の可読性に関子る実験的研究，照学誌，84 -11, pp.785-792 (2000).

(3) K. T. Mullen: The contrast sensitivity of human color vision to red-green and blue-yellow chromatic gratings, Journal of Physiology, 359, pp.381-400 (1985).

(4) K. T. Mullen and F. A. A. Kingdom : Colour contrast in form perception, P. Gouras (Ed.) The Perception of Colour, Vision and Visual Dysfunction, Vol.6, London : Macmillan Press (1991).

（5）瀬川かおり，内川惠二，栗木一郎：周辺視野におけるカテ ゴリカル色知覚,照学誌, 83, pp.860-868 (1999).

(6) G. Wyszecki and W. S. Stiles : Color science : Concepts and methods, quantitative data and formulas, New York: John Wiley (1982)

(7) J. M. Kraft and J. S. Werner : Spectral efficiency across the life span : flicker photometry and brightness match ing, J. Opt. Soc. Am. A, 11, pp.1213-1221 (1994).

(8) K. Knoblauch, F. Saunders, M. Kusuda, R. Hynes, M. Podgor, K. E. Higgins, and F. M. de Monasterio : Age and illuminance effects in the Farnsworth-Munsell 100hue test, Appl. Opt., 26, pp.1441-1448 (1987).

(9) R. M. Copenhaver and R. D. Gunkel : The spectral sensi- 
tivity of color defective subjects determined by electroretinography, Arch. Ophthalmol., 62, pp.55-68 (1959).

(10) 大島正光：人間工学, コロナ社 (1970).

(11) A. R. Robertson: The CIE 1976 color-difference formulae, Color Res. Appl., 2, pp.7-11 (1977).

(12) J. G. Robson : Spatial and temporal contrast sensitivity functions of the visual system, J. Opt. Soc. Am., 56, pp. 1141-1142 (1966).

(13) 神作博: 色光の誘目性について, 照学誌, 51, pp.684690 (1967).

(受付日 1999 年12月 3 日 $/$ 採録日2000年 7 月 6 日)

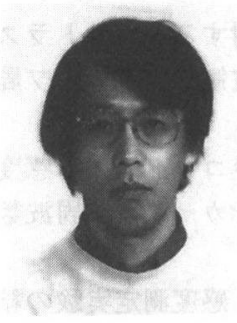

\section{舟川 政美 (正会員)}

日産自動車株式会社総合研究所車両交通研究 所

1956年 4 月生まれ. 1981年千葉大学人文学 部人文学科卒業. 1988年北海道大学大学院文 学研究科博士後期課程単位取得退学. 同年北星学園大学文学部助 手. 1990年日産自動車株式会社中央研究所基礎研究所入社, 視認 性・視界研究等に従事. 現在(社)人間生活工学研究センター（テ305 -0046 つくば市東1-1 生命工学工業技術研究所内） 一出向. 産 業技術基盤研究開発プロジェクト「人間行動適合型生活環境創出 システム技術」に従事. 放送大学非常勤講師. 文学博士. 日本視 覚学会, 日本心理学会, 基礎心理学会, ARVO, 日本色彩学会会 員. 